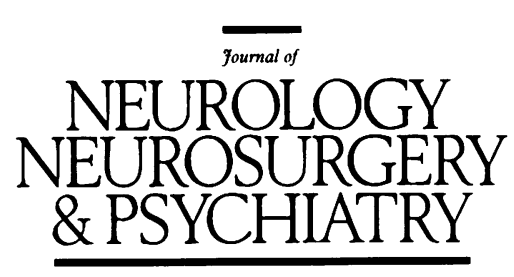

\title{
Editorial
}

\section{Medical treatments of acute spinal cord injury}

In the past three decades, advances in medical care have greatly increased survival and longevity of spinal-injured patients without improving neurological recovery. The second National Acute Spinal Cord Injury Study (NASCIS 2) changed this trend in 1990 by showing that methylprednisolone (MP) significantly improved motor and sensory recovery of spinal-injured patients compared with placebo-treatment. ${ }^{2}$ I shall summarise some lessons from the first trial (NASCIS 1) preceding NASCIS 2, describe the findings, discuss some controversial aspects of NASCIS 2, assess the impact of NASCIS 2 on spinal cord injury (SCI) research and care, and describe some promising new treatments.

\section{NASCIS 1}

MP is a synthetic glucocorticoid drug that has long been used by neurosurgeons to treat brain oedema. The doses used (100-1000 mg/day) greatly exceeded those necessary for the drug to act as a glucocorticoid. At doses of $1000 \mathrm{mg} /$ day, MP may be working as antioxidant or free radical scavenger at high doses ${ }^{2}$ NASCIS 1 began in 1979 to compare neurological recovery patterns of spinal-injured patients treated with "high dose" MP ( $1000 \mathrm{mg}$ bolus followed by $1000 \mathrm{mg} /$ day for 10 days) or "low dose" MP (100 mg bolus followed by $100 \mathrm{mg} /$ day for 10 days).

Between 1980-84, NASCIS 1 randomised 330 spinal-injured patients to the "high" and "low" dose MP treatments within 48 hours of injury. At 6 months ${ }^{4}$ and one year ${ }^{5}$ after injury, the two treatment groups did not differ significantly from each other in any respect, save a slight trend for increased wound infections in the MP-treated group. By 1985, however, data from several animal studies $^{6-12}$ suggested that too little MP was given too late in NASCIS 1 . The MP dose that optimally reduced tissue damage in animal studies was 2-10 times larger than the $1000 \mathrm{mg} /$ day dose tested in NASCIS 1 . Since much tissue damage occurs in injured spinal cords within the first 8 hours, MP treatment started 48 hours after injury is simply too late.

Although NASCIS 1 did not settle the question whether MP was effective, it paved the way for a successful NASCIS 2 in three ways. First, it established an efficient multicenter trial organisation which permitted early randomisation of a larger number of patients. Second, it focussed attention on the importance of early treatment with the appropriate dose. Third, it provided a strong rationale for a placebo-controlled trial.

\section{NASCIS 2}

NASCIS 2 randomised 487 spinal-injured patients within 12 hours after injury to three treatments: methylprednisolone $(30 \mathrm{mg} / \mathrm{kg}$ bolus followed by $5.4 \mathrm{mg} / \mathrm{kg} / \mathrm{h}$ for 23 hours), naloxone $(5.4 \mathrm{mg} / \mathrm{kg}$ bolus followed by $4.0 \mathrm{mg} / \mathrm{kg} / \mathrm{h}$ for 23 hours), and placebo. Motor deficits were assessed by grading strength of 14 múscle groups on each side of the body, using the standard 0-5 clinical scale. ${ }^{13}$ The grades were summed to give a maximum score of 70 for each side of the body. Because left- and right-sided scores did not differ significantly, only the right-side score was used for analysis. Sensory scores were obtained by grading 29 individual dermatomes on each side of the body for pinprick and light touch sensation individually, using a scale of $1-3$ and summed on the right side. Recovery was estimated from changes of summed scores from admission to follow up examinations at 6 weeks, 6 months, and a year after injury. Morbidity and mortality rates were monitored. Patients with severe co-morbidity, gunshot wounds, possible pregnancy, and a history of prerandomisation steroid or naloxone were excluded.

The study tested two hypotheses: 1) severely spinal-injured patients with total neurological loss below the lesion do not benefit from treatment and 2) early treatment is more effective than delayed treatment. To test the first hypothesis, the patients were stratified into three categories: those admitted with no function below the lesion ("plegic"), no motor but some sensory function ("plegic+"), or some motor function ("paretic"). To test the second hypothesis, the patients were divided into early and late treatment groups by the median time of initial therapy. The median time happened to be close to 8 hours.

At 6 weeks, 6 months, and one year after injury, the patients given MP within 8 hours after SCI had better motor and sensory recovery than placebo- and naloxone-treated patients, significantly so for motor function. Patients started on MP more than 8 hours after injury in fact had marginally worse motor function than placebo controls at one year $(p=0 \cdot 08)$. Both "plegic" and "paretic." patients receiving early MP treatment showed greater motor and sensory improvement than 
placebo-treated patients. Neither MP nor naloxone increased morbidity or mortality, compared with placebo. The study concluded that MP improved neurological recovery when given within 8 hours after SCI.

\section{Controversial aspects of NASCIS 2}

NASCIS 2 has been strongly criticised ${ }^{1415}$ for: 1) using summed motor and sensory scores to assess neurological deficits; 2) alleged post hoc stratification of patients by injury severity and treatment time; 3 ) inferring drug effect from small neurological score differences, and 4) not assessing functional recovery. These criticisms will be reviewed sequentially below.

Summed motor and sensory scores cannot distinguish between recovery due to descent of lesion level or more distal improvement. However, summed scores are objective and sensitive measures of neurologic deficits. Changes of summed scores directly reflect recovery. Moreover, scores from different parts of the body can be separately analysed to test specific hypotheses. For example, MP improved lumbosacral motor scores ( $p<$ 0.05 ), indicating significant recovery in distal segments. ${ }^{1}$

Stratification of patients by injury severity and treatment time was necessary to test the main study hypotheses and based on a priori criteria. The injury severity categories used in NASCIS 2 are identical to those in NASCIS $1^{45}$ and coincide with Frankel A, B, and C-D categories (table 1). ${ }^{16}$ Neurological recovery in placebo-treated "plegic" and "paretic" patients matched the expected poor and good prognoses in these two groups of patients. At a year after SCI, the former recovered $8 \%$ of lost motor function compared with $59 \%$ in the latter. Segregating patients by the median treatment time yielded equal size groups for maximum statistical power. Detailed analyses of admission neurological scores and other parameters revealed no significant differences among the different injury-time groups. ${ }^{17}$

The MP drug effects were statistically significant and robust. At one year after SCI, "plegic" patients given early MP recovered an average of 11 motor points compared with 4 points in placebo-treated patients $(p=0.019)$ and "paretic" patients given early MP recovered 24 points compared with 13 points in placebo-treated patients $(\mathrm{p}=$ $0.024)$. The average 7-11 point differences apply to each side of the body and reflect changes beyond that which placebo-treated patients recovered. In "plegic" patients, a 7 point difference due to MP can signify 4 muscle groups recovering from paralysis to useful strength (0 to 3-4

Table 11992 Revised American Spinal Injury Association Classification

A) Complete. No sensory or motor function preserved in sacral Complete. No sen.

B) Incomplete. Sensory but not motor function is preserved below the Incomplete. Sensory but not motor function is preserved below

C) Incomplete. Motor function is preserved below the neurologic level, and a majority of key muscles below the neurologic level have a and a majority of key muscle

D) Incomplete. Motor function is preserved below the neurologic level, and the majority of key muscles below the neurologic level have muscle grade greater than or equal to 3 .

E) Normal. Sensory and motor function is normal

Table 1: This classification approach differs from the traditional Franke classification ${ }^{16}$ in two critical respects. First, the definition of "complete" injur depends solely on the absence of sacral sparing in segments S4-5. A patient is considered complete if and only if sacral sparing is absent. Second, the difference between $C$ and $D$ is determined by whether or not a majority of key muscles below the neurologic level have grades $\geqslant 3$. The key muscles are: $C$ elbow flexors (biceps, brachialis), C6 wrist extensors (extensor carpi radialis longus and brevis), C7 elbow extensors (triceps), C8 finger flexors (flexor digitorum profundus of middle finger), $\mathrm{T} 1$ small finger adductors (abducto digiti minimi), 22 hip flexors (iliopsoas), 23 knee extensors (quadriceps), ankle digiti minimi), L2 hip fexors (iliopsoas), L3 knee extensors (quadriceps), ankle ankle plantar flexors (gastrocnemius, soleus) grade) or increased strength in as many as 14 muscles. The 11 point difference in "paretic" patients suggests that MP strengthened a majority of muscles tested, in addition to the recovery that usually occurs in such patients. The above statistics were based on "intention-to-treat" analyses of all randomised patients. A total of 15 of 487 patients did not receive drugs because they had pre-randomisation steroids or naloxone, severe co-morbidity, gunshot wounds, or no SCI; another 16 patients inadvertently received an incorrect dose or drug. Omitting these patients from the analysis increased the score differences and changed the p-values from $0 \cdot 02-0 \cdot 05$ to $0.001-0.01$. These observations strongly argue for a substantial drug effect.

NASCIS 2 did not directly evaluate function because no widely accepted functional outcome scale was available in 1985 when the study began. However, the motor score increases due to MP are consistent with at least a two Frankel-category change in both "plegic" and "paretic" patients. Also MP more than doubled the probability that patients improved from "plegic" to "paretic" $(p<0.05)$. Finally, more MP-treated patients showed lumbosacral motor $(11.8 \%, \mathrm{p} \sim 0.05)$, pinprick $(16.2 \%, \mathrm{p}<0.05)$ and touch $(17.9 \%, \mathrm{p}<0.05)$ recovery than placebo-treated patients. Thus MP is likely to have improved function.

\section{Impact of NASCIS 2 on SCI research}

The demonstration that a post-injury treatment can improve neurological recovery confirms the presence of secondary injury mechanisms in human SCI. ${ }^{1819} \mathrm{MP}$ scavenges oxygen free radicals and maximally inhibits lipid peroxidation at doses of $30 \mathrm{mg} / \mathrm{kg}$ in injured animal spinal cords. $^{20}$ The neuroprotective effects of MP consequently have been attributed to its antioxidant properties. ${ }^{21}$ However, MP is also a glucocorticoid with potent anti-inflammatory activities. Moreover, lipid peroxidation is a byproduct of tissue damage. Treatments that ameliorate tissue damage will also reduce lipid peroxidation. The correlative evidence obtained to date does not adequately test the lipid peroxidation hypothesis of MP action in SCI.

Three unexpected findings in NASCIS 2 provided insights into the nature and time course of secondary injury mechanisms in human SCI. First, plegic patients improved as a result of MP treatment. This finding suggests that these patients possess spinal axons that are at risk of further damage after injury. The long-held dogma that "complete" SCI patients cannot improve neurologically as a result of treatment should be reconsidered. Second, MP must be given within 8 hours to improve recovery. Since the 8 hour criterion is based on the median treatment time achieved in the study, the optimal treatment time may well be shorter than 8 hours. This therapeutic window is much shorter than expected. Third, patients receiving MP more than 8 hours after injury did not improve as much as placebo-treated patients. $^{22}$ This finding raises the disquieting possibility that delayed or prolonged MP treatment may be deleterious.

NASCIS 2 exposed several major gaps in preclinical studies of MP. Although MP is probably the most studied drug in SCI research, remarkably little is known about the optimal initiation time and duration of MP treatment for different injury severities. While several researchers have examined $30 \mathrm{mg} / \mathrm{kg}$ bolus given shortly after injury and followed by $2.5 \mathrm{mg} / \mathrm{kg} /$ hour for 48 hours, ${ }^{10}$ a single bolus given shortly after injury, ${ }^{23}$ or $15-30 \mathrm{mg} / \mathrm{kg} \mathrm{MP}$ boluses at 45 minutes and 3 hours, ${ }^{6}$ to date none has directly assessed the MP protocol tested in NASCIS 2, compared MP 
effects in graded SCI, or examined delayed MP treatment.

The discovery of an effective treatment has imposed an onerous burden on preclinical SCI studies. New SCI treatments should be shown to be equal or superior to MP. Preclinical studies should determine the optimal dose, duration and timing of a drug, alone or combined with MP, at different injury severities, and in comparison with vehicle and MP controls. These requirements are daunting. For example, assessing 3 doses (1x, 5x, 10x), 3 controls (vehicle, MP, MP + drug), at 3 treatment times (1, 6, 12 hours), 3 durations ( 1 hour, 24 hours, and 48 hours), and 3 injury severities (mild, moderate, severe) would require 243 treatment-injury groups. Few laboratories can afford such a tour de force. More reproducible SCI models, multicentre laboratory studies, and a better theoretical understanding of secondary injury mechanisms should reduce the number of experiments, spread the burden of preclinical testing, and allow more rational design of treatment protocols. Progress in identifying better SCI treatments depends critically on these developments.

\section{Impact of NASCIS 2 on clinical SCI care}

The NASCIS 2 results have remarkably altered attitudes towards SCI care. Before 1990, SCI was sometimes not treated as a true medical emergency. Spinal-injured patients were often taken to the nearest emergency room where they waited hours for diagnosis and treatment. By focusing attention on the first 8 hour period after injury, NASCIS 2 has encouraged rapid transport and therapy of spinal-injured patients. Most hospitals in the USA and elsewhere in the world are giving high-dose MP to spinal-injured patients shortly after injury. This trend may influence other aspects of acute SCI care. For example, more rapid transport may lead to earlier decompression and stabilisation of the spinal column.

An unanticipated development has been prophylactic use of MP to prevent iatrogenic spinal cord injury. Some surgeons routinely give a $2 \mathrm{~g}$ bolus of $\mathrm{MP}$ before a risky spinal procedure, continue at $5.4 \mathrm{mg} / \mathrm{kg} / \mathrm{h}$ for 24 hours if neurological deterioration occurs and discontinue the drug if not. This practice should be rigorously tested in a randomised clinical trial. The optimal dose, timing, duration, safety, and efficacy of prophylactic MP treatment are not known. Lower MP doses may suffice. Other antioxidants, for example, vitamin $\mathrm{E}$, may be safer and as effective. High dose MP is suitable for post-injury therapy since it rapidly penetrates into central nervous tissues.
Preoperative treatments do not have the same time requirements.

Some researchers believe that the NASCIS 2 results are discouraging clinical trials of new agents. Although NASCIS 2 has complicated trial design, it should not discourage further clinical trials. If the neurological recovery due to $\mathrm{MP}$ is not significant, $\mathrm{MP}$ should be a good control. If the neurological recovery is significant, then MP must be the standard against which all further treatments should be compared. In fact, NASCIS 2 has encouraged and facilitated clinical SCI trials. Research funding institutions and pharmaceutical companies have become more receptive to funding SCI research, realising that demonstrating drug efficacy in SCI may provide a gateway into other CNS injuries. Only one double-blind randomised clinical trial (NASCIS 1 ) had been carried out before NASCIS 2 . Since 1990, one clinical trial has been completed $^{24}$ and several multicentre trials are planned or underway.

NASCIS 2 accelerated standardisation of neurological scoring and SCI classification. Several organisations recently joined forces to develop a new international SCI standard, ${ }^{25}$ stipulating a new classification system (table 1) and specific motor and sensory scoring approaches (table 2). The standard introduces a new definition of "complete" SCI, based on absence of sacral sensory and motor function. ${ }^{26}$ The standard also recommends the Functional Independence Measure (FIM) which scores patients' abilities to carry out self care, sphincter control, mobility, locomotion, communication and social cognition. ${ }^{27}$ Designed to be compatible with existing SCI databases, the new standard will facilitate data sharing between institutions, allowing meta-analyses of data from multiple trials.

\section{Promising new treatments}

Many treatments have been reported to be beneficial in animal SCI studies. Table 3 summarises the glut of therapies which contrasts sharply with the poverty of the field only a decade ago. The drugs include antioxidants, opiate receptor antagonists, neurotransmitter receptor blockers, anti-inflammatory agents, enzyme blockers and others. Two promising drugs are now being tested in multicentre clinical SCI trials: tirilazad mesylate (TM) and the monosialic ganglioside GM1.

TM, a new 21 -aminosteroid, is a potent antioxidant ${ }^{28}$ with no glucocorticoid receptor activity. ${ }^{29}$ It has been shown to be neuroprotective in animal SCI models. ${ }^{30-33} \mathrm{~A}$ clinical trial comparing TM and MP would test the lipid

Table 2 Key muscles in the NASCIS 3 and ASIA motor scores

\begin{tabular}{|c|c|c|c|}
\hline Level & Action & NASCIS Key Muscles & ASIA Key Muscles \\
\hline $\begin{array}{l}\text { L2 } \\
\text { L3 } \\
\text { L4 } \\
\text { L5 } \\
\text { S1-S2 }\end{array}$ & $\begin{array}{l}\text { shoulder } \\
\text { elbow flexors } \\
\text { wrist extensors } \\
\text { elbow extensors } \\
\text { finger flexors } \\
\text { finger extensors } \\
\text { finger adductors } \\
\text { finger abductors } \\
\text { thumb opposition } \\
\text { hip flexors } \\
\text { knee extensors } \\
\text { ankle dorsiflexors } \\
\text { long toe extensors } \\
\text { knee flexors } \\
\text { ankle flexors } \\
\text { toe flexors }\end{array}$ & $\begin{array}{l}\text { deltoid } \\
\text { biceps } \\
\text { triceps } \\
\text { - extensor digitorum } \\
\text { lst dorsal interosseus } \\
\text { opponens pollicis } \\
\text { iliopsoas } \\
\text { quadriceps femoris } \\
\text { tibialis anterior } \\
\text { extensor hallucis longus } \\
\text { hamstring } \\
\text { gastrocnemius } \\
\text { peroneus long \& brevis }\end{array}$ & $\begin{array}{l}\text { biceps, brachialis } \\
\text { extensor carpi radialis } \\
\text { triceps } \\
\text { flexor digitorum profundus } \\
\text { abductor digiti minimi } \\
\text { iliopsoas } \\
\text { quadriceps } \\
\text { tibialis anterior } \\
\text { extensor hallucis longus } \\
\text { gastrocnemius, soleus }\end{array}$ \\
\hline
\end{tabular}

Table 2: Key muscles in National Acute Spinal Cord Injury (NASCIS) and American Spinal Injury Association (ASIA) motor scores are each graded on a scale of $0-5$ where 0 is total paralysis, 1 is palpable or visible contraction, 2 is active movement with full range of motion (ROM) under no gravity, 3 is full ROM against gravity, 4 is full ROM against moderate resistance, and 5 is normal. The ASIA score sums 10 muscle grades on both sides of the body for a total of 100 . The NASCIS score sums 14 muscle grades on the right side for a total of 70 . 
Table 3 Experimental treatments of acute SCI

\begin{tabular}{|c|c|c|c|}
\hline Drug & Action & Type & Selected References \\
\hline Methylprednisolone & $\begin{array}{l}\text { Glucocorticoid } \\
\text { - Antioxidant }\end{array}$ & $\begin{array}{l}+\mathrm{RCT} \\
+ \text { cat }\end{array}$ & 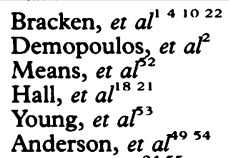 \\
\hline $\begin{array}{l}\text { GM1 (Monosialic } \\
\text { ganglioside) }\end{array}$ & $\begin{array}{l}\text { ? intracellular } \\
\text { messenger systems, } \\
\text { ? interacts with } \\
\text { neurotransmitter and } \\
\text { growth factor receptors }\end{array}$ & $\begin{array}{l}+\mathrm{RCT} \\
\pm \text { cat }\end{array}$ & 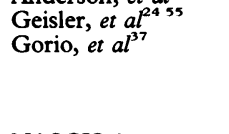 \\
\hline $\begin{array}{l}\text { Tirilazad mesylate } \\
\text { (21-aminosteroid, } \\
\text { "lazaroid", U74006F) }\end{array}$ & Antioxidant & $\begin{array}{l}=\mathrm{RCT} \\
+ \text { cat }\end{array}$ & $\begin{array}{l}\text { NASCIS } 3 \\
\text { Anderson, } e t a l^{3356} \\
\text { Hall, et al }\left.\right|^{830-32}\end{array}$ \\
\hline $\begin{array}{l}\text { Thyrotropin releasing } \\
\text { hormone }\end{array}$ & $\begin{array}{l}\text { ? kappa opiate } \\
\text { receptor blocker } \\
\text { release thyrotropin }\end{array}$ & $\begin{array}{l}\text { + cat } \\
\text { + rat }\end{array}$ & $\begin{array}{l}\text { Faden, et } a l^{47} \\
\text { Faden, et } a l^{48}\end{array}$ \\
\hline $\begin{array}{l}\text { Vitamin } \mathrm{E} \text { and } \\
\text { selenium }\end{array}$ & antioxidant & + cat & $\begin{array}{l}\text { Anderson, et } a l^{49} 50 \\
\text { Saunders, et } a l^{1} \\
\text { Hall, et } a l^{20}\end{array}$ \\
\hline Naloxone. & $\begin{array}{l}\text { mu opiate } \\
\text { receptor blocker }\end{array}$ & $\begin{array}{l}-\mathrm{RCT} \\
+ \text { cat }\end{array}$ & $\begin{array}{l}\text { Bracken, et } a l^{141022} \\
\text { Faden, et } a l^{7-59} \\
\text { Young, et at } a l^{60} \\
\text { Flamm, et } a l^{162}\end{array}$ \\
\hline Nalmefene & $\begin{array}{l}\text { kappa opiate } \\
\text { receptor blocker }\end{array}$ & + rat & Faden, et $a t^{45} 46$ \\
\hline YM-14673 & $\begin{array}{l}\text { a TRH analog } \\
\text { ? kappa opiate } \\
\text { receptor blocker }\end{array}$ & + rat & Faden, et $a l^{3-65}$ \\
\hline MK801 & $\begin{array}{l}\text { NMDA } \\
\text { receptor blocker }\end{array}$ & + rat & Faden, et al ${ }^{66-69}$ \\
\hline Mianserin & $\begin{array}{l}\text { Serotonin } \\
\text { receptor blocker }\end{array}$ & + rat & Salzman, et $a t^{570}$ \\
\hline BW755C & $\begin{array}{l}\text { cyclo-oxygenase } \\
\text { and lipoxygenase } \\
\text { inhibitor }\end{array}$ & + rat & Faden, et $a l^{71}$ \\
\hline Ibuprofen & $\begin{array}{l}\text { cyclo-oxygenase } \\
\text { inhibitor }\end{array}$ & + cat & Hall, et $a l^{72}$ \\
\hline Protease inhibitors & $\begin{array}{l}\text { prevents damage } \\
\text { to neurofilaments }\end{array}$ & + rat & Iwasaki, et $a l^{3374}$ \\
\hline Nimodipine & $\begin{array}{l}\text { blocker of L-type } \\
\text { calcium channels }\end{array}$ & \pm rat & Tator, et $a l^{756}$ \\
\hline
\end{tabular}

Table 3: The drugs, the presumed actions, randomized clinical trials(RCT) or animal models with positive $(+)$, mixed $( \pm)$, or ongoing $(=)$ studies, and selected references are listed.

peroxidation hypothesis of secondary tissue damage in SCI. A third National Acute Spinal Cord Injury Study (NASCIS 3) is underway, comparing three treatment arms: MP 24 hours $(30 \mathrm{mg} / \mathrm{kg}$ within 8 hours followed by MP $5.4 \mathrm{mg} / \mathrm{kg} / \mathrm{h}$ for 24 hours), MP 48 hours $(30 \mathrm{mg} / \mathrm{kg}$ followed by MP $5.4 \mathrm{mg} / \mathrm{kg} / \mathrm{h}$ for 48 hours), and TM 48 hours $(30 \mathrm{mg} / \mathrm{kg} \mathrm{MP}$ followed by TM $2.5 \mathrm{mg} / \mathrm{kg}$ every 6 hours for 48 hours). The study asks three questions. Is the optimal MP initiation time shorter than 8 hours? Is 48 hours of MP better than 24 hours? Can TM substitute for MP after an initial bolus of MP? The study will provide risk-to-benefit assessments of the three treatment protocols.

The ganglioside GM1 was recently evaluated in a randomised placebo-controlled trial involving 34 spinal-injured patients. ${ }^{24}$ All the patients received low dose MP (250 mg intravenously followed by $125 \mathrm{mg}$ intravenously every 6 hours for 72 hours). Intravenous GM1 (100 mg/day started 48-72 hours after injury and continued for 18-32 days) improved lower limb but not upper limb scores at 6-12 months. Ganglioside GM1-treated patients had a significantly higher probability of achieving a two Frankel-category improvement compared with placebo controls. A multi-centre trial is being planned to compare MP+ GM1 against MP.

Neither the sites nor mechanisms of GM1 action are known. Normally present in central nervous tissues, ${ }^{34}$ GM1 has been reported to facilitate recovery from brain $^{3536}$ and peripheral nerve lesions, ${ }^{37}$ to increase neurite outgrowth, ${ }^{38}$ to inhibit neuronal degeneration, ${ }^{39-41}$ and to enhance reflex recovery in transected spinal cords after fetal tissue transplants. ${ }^{42}$ Ganglioside GM1 also stimulates and preserves protein kinases ${ }^{43}$ and prevents glutamate-induced neuronal excitotoxicity. ${ }^{44}$ There is no dearth of hypotheses to explain beneficial GM1 effects.
Several other drugs are potential candidates for clinical trial. For example, nalmefene is a long-acting opiate antagonist that has been reported to be as or more effective than naloxone in animal SCI models ${ }^{45} \mathrm{TRH}^{47}$ and TRH analogs ${ }^{48}$ likewise have also been reported to be superior to naloxone. Although NASCIS 2 did not find a major therapeutic benefit of naloxone, the trial did show that the drug was safe and revealed a trend for better motor and sensory 'recovery in naloxone-treated patients compared with placebo controls. Another possibility is vitamin E which has been shown to be effective in animal SCI when given before injury. ${ }^{20-51}$ The safety profile of vitamin $\mathrm{E}$ makes it particularly attractive for comparison with MP in a clinical trial of pre-operative therapy.

In conclusion, we have come a long way from the sense of helplessness that dominated the SCI field a few years ago. NASCIS 2 is a starting point for developing better therapy for acute SCI. Ganglioside GM1 may provide a means of manipulating recovery processes during the subacute period after SCI. Many other drugs are awaiting further preclinical and clinical investigation. Hope is once more in the hearts and minds of physicians and researchers in the field.

WISE YOUNG

Department of Neurosurgery,

NYU Medical Center,

550 First Avenue,

New York, NY 10016, USA

1 Bracken MB, Shepard MJ, Collins WF, et al. A randomized controlled trial of methylprednisolone or naloxone in the treatment of acute spinal-cord injury: Results of the Second National Acute Spinal Cord Injury Study. injury: Results of the Second National

2 Demopoulos HB, Flamm ES, Seligman MC, et al. Further studies on free radical pathology in the major central nervous system disorders: Effect of very high doses of methylprednisolone on the functional outcome, morphology and chemistry of experimental spinal cord impact injury. Can 
I Physiol Pharmacol 1981;60:1415-24

3 Demopoulos HB, Flamm ES, Pietronigro DD, it al. The free radical pathology and the microcirculation in the major central nervous system disorders. Acta Physiol Scand 1980;492:91-119.

4 Bracken MB, Collins WF, Freeman DF, et al. Efficacy of methylprednisolone in acute spinal cord injury. $\mathcal{F}$ Am Med Assoc 1984;251:45-52.

5 Bracken MB, Shepard MJ, Hellenbrand KG, et al. Methylprednisolone and neurological function 1 year after spinal cord injury. $\mathcal{F}$ Neurosurg 1985 63:704-13.

6 Young W, DeCrescito V, Flamm ES, et al. Pharmacological therapy of acute spinal cord injury: studies of high dose methylprednisolone and naloxone. Neurosurg 1988;34:675-97.

7 Braughler JM, Hall ED. Acute enhancement of spinal cord synaptosomal $(\mathrm{Na}+\mathrm{K}+)$ - ATPase activity in cats following intravenous methylprednisolone. Brain Res 1981;219:464-9.

8 Braughler JM, Hall ED. Correlation of methylprednisolone pharmacokinetics in peroxidation and motor neuron function. $₹$ Neurosurg 1981;56:838-44.

9 Braughler JM, Hall ED. "High-dose" methylprednisolone and CNS injury [letter]. $\mathcal{F}$ Neurosurg 1986;6:985-6.

10 Braughler JM, Hall ED, Means ED, et al. Evaluation of an intensive methylprednisolone sodium succinate dosing regimen in experimental spinal cord injury. 7 Neurosurg 1987;67:102-5.

11 Hall ED, Braughler JM. Effects of methylprednisolone on spinal cord lipid peroxidation and $(\mathrm{Na}+-\mathrm{K}+)$-ATPase activity: dose response analysis during the first hour after contusion injury in the cat. $f$ Neurosurg 1982; 57:247-53.

12 Hall ED, Wolf DL. Methylprednisolone preservation of motor nerve function during early degeneration. Exp Neurol 1984;84:715-20.

13 Nerve Injuries Committee. War memorandum No 7. 2nd ed. London: Medical Research Council, HMSO, 1943.

14 Rosner MJ. National acute spinal cord injury study of methylprednisolone or naloxone [letter]. Neurosurgery 1991;28:628-9.

15 Hanigan WC, Anderson RJ. Commentary on NASCIS-2. I Spinal Disorders 1992;5:125-31

16 Frankel HL, Hancock DO, Hyslop G, et al. The value of postural reduction in the initial management of closed injuries of the spine with paraplegia and tetraplegia. I. Paraplegia 1969;7:179-92.

17 Young W, Bracken MB. The Second National Acute Spinal Cord Injury Study. fournal of Neurotrauma 1992;9:S429-51.

18 Hall ED. The neuroprotective pharmacology of methylprednisolone. $f$ Neurosurg 1992;76:13-22.

19 Young W. Clinical trials and experimental therapies of acute spinal cord injury. In: Vincken DJ, ed. Handbook of clinical neurology. Amsterdam: Holland Elsevier, 1992:(in press).

20 Hall ED, Braughler JM. Role of lipid peroxidation in post-traumatic spinal cord degeneration: a review. Cent nerv syst trauma 1986;3:281-94.

21 Hall ED, Braughler JM. Glucocorticoid mechanisms in acute spinal cord injury: a review and therapeutic rationale. Surg Neurol 1982;18:320-7.

22 Bracken MB, Shepard MJ, Collins WF, et al. Methylprednisolone or naloxone in the treatment of acute spinal cord injury: 1 year follow up data. Results of the second National Acute Spinal Cord Injury Study. $\mathcal{F}$ Neurosurgery 1992;76:23-31.

23 Holtz A, Nystrom B, Gerdin B. Effect of methylprednisolone on motor function and spinal cord blood flow after spinal cord compression in rats. Acta Neurol Scand 1990;82:68-73.

24 Geisler FH, Dorsey FC, Coleman WP. Recovery of motor function after spinal cord injury - a randomized, placebo-controlled trial with GMsanglioside. New Engl f Med 1991;324:1829-38.

25 American Spinal Injury Association. Standards for neurological classification of spinal cord injury, Rev 1992. Chicago: American Spinal Injury Association, 1992.

26 Waters RL, Adkins RH, Yakura JS. Definition of complete spinal cord injury. Paraplegia 1991;9:573-81.

27 Hamilton BB, Fuhrer MJ. Functional Independence Measure. In: Hamilton BB, Fuhrer MJ, ed. Rehabilitation outcomes: analysis and measurement. Baltimore: Brooks, 1987:137-47.

28 Braughler JM, Pregenzer JF, Chase RL, et al. Novel 21-amino steroids as potent inhibitors of iron-dependent lipid peroxidation. 7 Biol Chem 1987; 262:10438-40.

29 Hall ED, Braughler JM, McCall JM. Antioxidant effects in brain and spinal cord injury. F Neurotrauma 1992;9:S165-S72.

30 Hall ED. Beneficial effects of the 21 -aminosteroid U74006F in acute CNS trauma and hypovolemic shock. Acta Anaesth Belg 1987;38:42-5.

31 Hall ED. Effects of the 21 -aminosteroid U74006F on posttraumatic spinal cord ischemia in cats. $\mathcal{f}$ Neurosurg 1988;68:462-5.

32 Hall ED, Yonkers PA, Horan KL, et al. Correlation between attenuation of posttraumatic spinal cord ischemia and preservation of tissue vitamin $\mathrm{E}$ by the 21-aminosteroid U74006F: evidence for an in vivo antioxidant mechanism. F Neurotrauma 989;6:169-76.

33 Anderson DK, Hall ED, Braughler JM, et al. Effect of delayed administration of U74006F (Tirilazad Mesylate) on recovery of locomotor functio after experimental spinal cord injury. $\mathcal{F}$ Neurotrauma 1991;8:187-92.

34 Ando S. Gangliosides in the nervous system. Neurochem Int 1983;5: 507-37.

35 Sabel BA, Slavin MD, Stein DG. GM-1 ganglioside treatment facilitates behavioral recovery from bilateral brain damage. Science 1984; 225:340-42.

36 Sabel BA, Dunbar GL, Stein DG. Gangliosides minimize behavioral deficits and enhance structural repair after brain injury. F Neurol Sci 1984; 12:429-43.

37 Gorio A, DiGiulio AM, Young W, et al. GM1 effects on chemical, traumatic and peripheral nerve induced lesions to the spinal cord. In: Goldberger ME, Gorio A, Murray M, ed. Development and plasticity of the mammalian spinal cord. Padova: Liviana Press, 1986:227-42.

38 Barletta E, Bremer EG, Culp LA. Neurite outgrowth in dorsal root neuronal hybrid clones modulated by ganglioside GM1 and disintegrins. Exp Cell Res 1991;193:101-11.

39 Cuello A, Stephens P, Tagari P, et al. Retrograde changes in the nucleus basalis of the rat are prevented by exogenous ganglioside GM1. Brain Res 1986;376:373-7.

40 Sabel BA, Del Mastro R, Dunbar GL, et al. Reduction of anterograde degeneration in brain damaged rats by GM-1 gangliosides. Neurosci Res 1987;77:360-6.

41 Sabel BA, Gottlieb J, Schneider GE. Exogenous GM1 gangliosides protect gainst retrograde degeneration following posterior neocortex lesions in developing hamsters. Brain Res 1988;459:373-80.

42 Commissiong JW, Toffano G. The effect of GM1 ganglioside on coerulospinal, noradrenergic, adult neurons and fetal monoaminergic neurons transplanted into the transected spinal cord of the adult rat. Brain Res 1986;380:205-15.

43 Hilbush BS, Levine JM. Stimulation of a $\mathrm{Ca} 2+$-dependent protein kinase by GM1 ganglioside in nerve growth factor-treated PC12 cells. Proc Natl Acad Sci USA 1991;88:561 6-20.

44 Skaper SD, Leon A, Facci L. Ganglioside GM1 prevents death induced by excessive excitatory neurotransmission in cultured hippocampal pyramidal neurons. Neurosci Lett 1991;126:98-101.

45 Faden AI, Sacksen I, Noble LJ. Opiate-receptor antagonist nalmefene improves neurologic recovery after traumatic spinal cord injury in rats through a central mechanism. I Pharmacol Exp Ther 1988;245:742-8.

46 Vink R, McIntosh TK, Rhomhanyi R, et al. Opiate antagonist nalmefene improves intracellular free $\mathrm{Mg} 2+$, bioenergetic state, and neurologic outcome following traumatic brain injury in rats. F Neurosci 1990; 10:3524-30.

47 Faden AI, Jacobs TP, Smith MT. Comparison of thyrotropin-releasing hormone (TRH), naloxone, and dexamethasone treatments in experimental spinal injury. Neurology 1983;33:673-8.

48 Faden AI, Jacobs TP. Effect of TRH analogs on neurologic recovery after experimental spinal trauma. Neurology 1985;35:1331-4.

49 Anderson DK, Means ED. Alpha-tocopherol, mannitol, and methylprednisolone prevention of $\mathrm{FeCl}_{2}$-initiated free radical induced lipid peroxidation in splnal cord. In: Novelli U, ed. Oxygen free radicals in shock. Basel: Karger, 1986:224-30.

50 Anderson DK, Waters TR, Means ED. Pretreatment with alpha tocopherol enhances neurologic recovery after experimental spinal cord compression injury. 7 Neurotrauma $1988 ; 5: 61-7$.

51 Saunders RD, Dugan LL, Demediuk P, et al. Effects of methylprednisolone and the combination of alpha-tocopherol and selenium on arachidonic acid metabolism and lipid peroxidation in traumatized spinal cord tissue. Neurochem 1987;49:24-31.

52 Means ED, Anderson DK, Waters TR, et al. Effect of methylprednisolone in compression trauma to the feline spinal cord. 7 Neurosurg 1981;55: $200-8$.

53 Young W, Flamm ES. Effect of high dose corticosteroid therapy on blood flow, evoked potentials, and extracellular calcium in experimental spinal injury. F Neurosurg 1982;57:667-73.

54 Anderson DK, Saunders RD, Demediuk P, et al. Lipid hydrolysis and peroxidation in injured spinal cord: partial protection with methylprednisolone or vitamin E and selenium. Cent Nerv Syst Trauma 1985;2: 57-67.

55 Geisler FH, Dorsey FC, Coleman WP. GM-1 ganglioside in human spinal cord injury. $\mathcal{F}$ Neurotrauma 1992;9:S407-16.

56 Anderson DK, Braughler JM, Hall ED, et al. Effects of treatment with $\mathrm{U} 74006 \mathrm{~F}$ on neurological outcome following experimental spinal cord injury. Neurosurg 1988;69:562-7.

57 Faden AI, Jacobs TP, Mougey E, et al. Endorphins in experimental spinal injury: Therapeutic effect of naloxone. Ann Neurol 1981;10:326-32.

58 Faden AI, Jacobs TP, Zivin JA. Naloxone but not TRH improves neurological recovery following spinal cord ischemia in the rabbit. Stroke $1983 ; 14: 1-15$

59 Faden AI, Jacobs TP, Zivin JA. Naloxone but not a delta antagonist improves neurological recor

60 Young W, Flamm ES, Demopoulos HB, et al. Effect of naloxone on posttraumatic ischemia in experimental spinal contusion. 7 Neurosurg 1981;55:209-19.

61 Flamm ES, Young W, Demopoulos HB, et al. Experimental spinal cord injury: treatment with naloxone. Neurosurgery 1982;10:227-31.

62 Flamm ES, Young W, Collins WF, et al. A phase I trial of naloxone treatment in acute spinal cord injury. $\mathcal{F}$ Neurosurg 1985;63:390-97.

63 Faden AI, Sacksen I, Noble LJ. Structure-activity relationships of TRH analogs in rat spinal cord injury. Brain Res $1988 ; 448: 287-93$.

64 Faden AI. TRH analog YM-14673 improves outcome following traumatic brain and spinal cord injury in rats: dose-response studies. Brain Res 1989;486:228-35.

65 Puniak MA, Freeman GM, Agresta CA, et al. Comparison of a serotonin antagonist, opioid antagonist, and TRH analog for the acute treatment of experimental spinal trauma. $\mathcal{F}$ Neurotrauma 1991;8:193-203.

66 Faden AI, Simon RP. A potential role for excitotoxins in the pathophysiology of spinal cord injury. Ann Neurol 1988;23:623-6.

67 Faden AI, Lemke $M$, Simon RP, et al. N-methyl-D-aspartate antagonist MK801 improves outcome following traumatic spinal cord injury in rats: Behavioral, anatomic, and neurochemical studies. $\mathcal{F}$ Neurotrauma 1988; 5:33-45.

68 Faden AI, Ellison JA, Noble LJ. Effects of competitive and non-competitive NMDA receptor antagonists in spinal cord injury. Eur $f$ Pharmacol 1990;175:165-74

69 Yum SW, Faden AI. Comparison of the neuroprotective effects of the $\mathrm{N}$-methyl-D-aspartate antagonist MK-801 and the opiate-receptor antagonist nalmefene in experimental spinal cord ischemia. Arch Neurol 1990;47:277-81.

70 Salzman SK, Puniak MA, Liu Z-j, et al. The serotonin antagonist mianserin improves functional recovery following experimental spinal trauma. Ann Neurol 1991;30:533-41.

71 Faden AI, Lemke M, Demediuk P. Effects of BW755C, a mixed cyclooxygenaselipoxygenase inhibitor, following traumatic spinal cord injury in rats. Brain Res 1988;463:63-8.

72 Hall ED, Wolf DL. A pharmacological analysis of the pathophysiological mechanisms of posttraumatic spinal cord ischemia. $f$ Neurosurg 1986;64:951-61.

73 Iizuka $\mathrm{H}$, Iwasaki Y, Yamamoto $\mathrm{T}$, et al. Morphometric assessment of drug effects in experimental spinal cord injury. F Neurosurg 1986;65:92-8.

74 Iwasaki Y, Yamamoto H, Iizuka H, et al. Suppression of neurofilament degradation by protease inhibitors in experimental spinal cord injury. Brain Res 1987; 406:99-104.

75 Guha A, Tator CH, Piper I. Increase in rat spinal cord blood flow with the calcium channel blocker, nimodipine. $\mathcal{F}$ Neurosurg 1985;63:250-9.

76 Tator CH, Fehlings MG. Review of the secondary injury theory of acute spinal cord trauma with emphasis on vascular mechanisms. $\mathcal{F}$ Neurosurg 1991;75:15-26. 